\title{
PELATIHAN KETERAMPILAN SADARI UNTUK DETEKSI DINI KANKER PAYUDARA PADA WANITA USIA SUBUR (WUS) DI DESA BUKUR TULUNGAGUNG TAHUN 2018
}

\author{
Eko Winarti ${ }^{1}$, Yunnatul Munawaroh ${ }^{2}$ \\ ${ }^{1,2}$ Prodi Kebidanan D.IV FIK Universitas Kadiri
}

\begin{abstract}
ABSTRAK
SADARI (Pemeriksaan Payudara Sendiri) merupakan cara sederhana menemukan tumor payudara sedini mungkin (Widiastuti, 2009). Berdasarkan studi pendahuluan di Desa Bukur pada bulan desember 2017 didapatkan sebagian besar WUS belum tahu tentang deteksi dini kanker payudara di Desa Bukur kota Tulungagung tahun 2017.

Hasil pengabdian masyarakat menunjukkan bahwa keterampilan SADARI sebelum diberikan pelatihan pada kelompok Intervensi dan kelompok Kontrol yaitu sebagian besar (69\%) responden tidak terampil melakukan SADARI pada kelompok Intervensi, sebagian besar (56\%) responden tidak terampil melakukan SADARI pada kelompok Kontrol sedangkan Keterampilan setelah diberikan pelatihan pada kelompok Intervensi dan Kontrol yaitu hampir seluruhnya (88\%) responden terampil melakukan SADARI. Sebagai tenaga kesehatan upaya yang harus dilakukan adalah meningkatkan kemauan serta pemahaman sehingga WUS mampu melakukan dan memahami pentingnya melakukan SADARI dengan memberikan pelatihan
\end{abstract}

Kata kunci : WUS, SADARI, Kanker Payudara 


\begin{abstract}
BSE (Breast Self Examination) is a simple way to find breast tumors as early as possible (widiastuti, 2009). BSE (Breast Self-Examination) is a simple way of finding breast tumors as early as possible (Widiastuti, 2009). Based on a preliminary study in Bukur Village in December 2017, it was found that most of the WUS did not know about early detection of breast cancer in the village of Bukur, Tulungagung in 2017.

The results showed that the skills of Breast Self Examination (BSE) before being given training in the intervention group that is largely $(69 \%)$ of respondents unskilled perform BSE, and in the control group that is largely (56\%) of respondents did not perform BSE sedagkan skilled skills after being given training in the intervention group is almost entirely ( $88 \%$ ) of respondents / skilled perform BSE and the control group. the majority of respondents $(75 \%)$ of respondents perform BSE As a skilled health worker attempts to do is to increase the willingness and understanding so that WUS not only perform BSE alone but also understand the importance of doing breast self-exam by providing more training
\end{abstract}

Keywords: women of childbearing age (WUS), Breast Self Examination (BSE), Breast Cancer 


\section{PENDAHULUAN}

Setiap dua dari 10.000 perempuan di dunia diperkirakan akan mengalami kanker payudara setiap tahunnya. Kanker payudara merupakan salah satu penyebab utama kematian yang diakibatkan oleh kanker pada perempuan di seluruh dunia (Depkes RI, 2009). Diantara seluruh kanker yang ada, kanker payudara adalah salah satu kanker yang paling sering ditemukan. Menurut Dr Dradjat, di Indonesia sendiri kasus kanker payudara terus meningkat. Pada tahun 2004, tercatat ada 15,1 persen kasus kanker payudara dari semua kasus kanker yang ada. Di tahun 2008, jumlahnya meningkat menjadi 18,5 persen (Wahyuningsih, 2012).

Menurut WHO (2008), prevalensi kejadian kanker payudara di dunia diperkirakan kurang lebih 16\% dari pada semua kasus kanker pada wanita. Diperkirakan kurang lebih 510.000 wanita meninggal dunia pada tahun 2004 dan $69 \%$ daripada angka tersebut merupakan kejadian yang berlaku di negara yang berkembang.

Di Indonesia, kanker payudara merupakan kanker kedua paling banyak diderita kaum wanita setelah kanker mulut/leher rahim. Kanker payudara umumnya menyerang wanita yang telah berumur lebih dari 40 tahun. Namun demikian, wanita muda juga bisa terserang kanker ini (Mardiana, 2009). Data dari yayasan kanker Indonesia pada lima tahun terakhir menyebutkan kejadian kanker payudara menempati urutan pertama 32\%, dari total jumlah kasus kanker. Total penderita kanker payudara $40 \%$ berobat pada stadium awal dan $30 \%$ dari jumlah penderita kanker terdeteksi stadium lanjut lokal, dan $30 \%$ dengan metastasis (Haryono 2007).

Berdasarkan studi pendahuluan yang dilakukan di Desa Bukur, WUS di kelurahan tersebut banyak yang tidak tahu dan tidak pernah mendapatkan pelatihan tentang Pemeriksaan Payudara sendiri (SADARI). Sehingga mereka acuh dan merasa tabu untuk melakukan pemeriksaan payudara sendiri. Mereka menganggap bahwa deteksi dini kanker payudara harus berobat ke rumah sakit dan mengeluarkan biaya yang cukup mahal, sehingga mereka enggan untuk 
melakukan deteksi dini kanker payudara. Selain itu mereka menganggap bahwa kanker payudara tidak dapat disembuhkan sama sekali.

Untuk dapat mengubah perilaku masyarakat dapat diberikan Pelatihan yang disesuaikan dengan tingkat pendidikan dan budaya yang terdapat di daerah tersebut. Pelatihan ini dapat dilakukan oleh petugas kesehatan atau anggota masyarakat yang sebelumnya telah ditatar terlebih dahulu. Selain itu keterlibatan pejabat yang berwenang atau pemerintah daerah setempat untuk ikut memantau setiap Pelatihan yang dilakukan secara kesinambungan sangat diperlukan (Herijulianti, 2011).

Untuk menemukan gejala awal kanker payudara dapat dideteksi sendiri oleh kaum wanita, jadi tidak perlu seorang ahli untuk menemukan awal kanker payudara. Secara rutin wanita dapat melakukan metode SADARI dengan cara memijat dan meraba seputar payudaranya untuk mengetahui ada atau tidaknya benjolan di sekitar payudara (Manuaba, 2007).

\section{MASALAH}

Pengabdian masyarakat ini menunjukkan banyak WUS yang belum tahu dan tidak pernah mendapatkan pelatihan tentang Pemeriksaan Payudara sendiri (SADARI). Sehingga mereka acuh dan merasa tabu untuk melakukan pemeriksaan payudara sendiri. Mereka menganggap bahwa deteksi dini kanker payudara harus berobat ke rumah sakit dan mengeluarkan biaya yang cukup mahal, sehingga mereka enggan untuk melakukan deteksi dini kanker payudara. Selain itu mereka menganggap bahwa kanker payudara tidak dapat disembuhkan sama sekali.

\section{METODE}

\subsection{Cara yang digunakan untuk menyelesaikan masalah}

Pelatihan SADARI (Pemeriksaan Payudara Sendiri) dibekali pada WUS untuk meningkatkan keterampilan WUS dalam melakukan deteksi dini kanker payudara sehingga kejadian kanker payudara dapat di cegah secara dini dengan melakukan pemeriksaan payudara sendiri pada WUS di Desa Bukur. 


\subsection{Tekhnik Pengumpulan Data}

Untuk mengetahui kebutuhan WUS yang berkaitan dengan kesehatan reproduksi dilakukan wawancara langsung pada WUS. Selanjutnya, observasi serta pemberian kuisioner pre test pada responden selanjutnya dilakukan pelatihan kemudian diberikan kuesioner lagi sebagai post test dilakukan untuk melengkapi data. Skala keterampilan digunakan untuk mengetahui keterampilan WUS dalam melakukan SADARI

\subsection{Tekhnik Analisa data}

Analisis univariate dilakukan dengan deskriptif, sedangkan analisa bivariate dilakukan dengan menggunakan uji Wilcoxon

\section{HASIL DAN PEMBAHASAN}

\section{A. HASIL}

a. Data Umum

1. Karakteristik Responden Berdasarkan Usia

Karakteristik responden berdasarkan Usia di Desa Bukur Tulungagung Tahun 2018 dapat dilihat pada tabel berikut :

Tabel 1. Distribusi frekuensi karakteristik responden menurut Usia di Desa Bukur Tulungagung Tahun 2018

\begin{tabular}{cccccccc}
\hline No & Usia & Audiovisual & $\begin{array}{c}\text { Prosentase } \\
(100 \%)\end{array}$ & Leaflet & $\begin{array}{c}\text { Prosentase } \\
(100 \%)\end{array}$ & $\begin{array}{c}\text { JML } \\
\text { Prosentase } \\
(100 \%)\end{array}$ \\
\hline 1 & $<20$ tahun & 5 & 31 & 2 & 13 & 7 & 22 \\
2 & $20-35$ tahun & 10 & 63 & 11 & 69 & 21 & 66 \\
3 & $>35$ tahun & 1 & 6 & 3 & 19 & 4 & 12 \\
\hline & Total & 16 & 100 & 16 & 100 & 32 & 100 \\
\hline
\end{tabular}

Berdasarkan tabel 1. dapat diinterpretasikan bahwa pada kelompok Audiovisual terdapat 10 orang (63\%) berusia 20-35 tahun dan kelompok Leaflet terdapat 11 (69\%) berusia 20-35 tahun, sehingga dapat disimpulkan bahwa sebagian besar 21 (66\%) responden berusia 20-35 tahun.

2. Karakteristik Responden Berdasarkan Pekerjaan 
Karakteristik responden berdasarkan pekerjaan di Desa Bukur Tulungagung Tahun 2018 dapat dilihat pada tabel berikut :

Tabel 2. Distribusi frekuensi karakteristik responden menurut pekerjaan di Desa Bukur Tulungagung Tahun 2018

\begin{tabular}{cccccc}
\hline No & Pekerjaan & Audiovisual & $\begin{array}{c}\text { Prosentase } \\
(100 \%)\end{array}$ & Leaflet & $\begin{array}{c}\text { Prosentase } \\
(100 \%)\end{array}$ \\
\hline 1 & IRT & 6 & 38 & 3 & 19 \\
2 & Swasta & 9 & 56 & 8 & 50 \\
3 & Wiraswasta & 1 & 6 & 4 & 25 \\
4 & PNS & 0 & 0 & 1 & 6 \\
\hline & Total & 16 & 100 & 16 & 100 \\
\hline
\end{tabular}

Berdasarkan tabel 2. dapat diinterpretasikan bahwa pada kelompok Audiovisual terdapat 9 orang (56\%) Bekerja sebagai Swasta. Dan kelompok Leaflet terdapat 8 (50\%) Bekerja sebagai Swasta, sehingga dapat disimpulkan bahwa sebagian besar (53\%) responden Bekerja sebagai Swasta.

3. Karakteristik Responden Berdasarkan Pendidikan

Karakteristik responden berdasarkan Status Pendidikan di Desa Bukur Tulungagung Tahun 2018 dapat dilihat pada tabel berikut :

Tabel 3. Distribusi frekuensi karakteristik responden menurut pendidikan di Desa Bukur Tulungagung Tahun 2018

\begin{tabular}{clcccc}
\hline No & Pendidikan & Audiovisual & $\begin{array}{c}\text { Prosentase } \\
(100 \%)\end{array}$ & Leaflet & $\begin{array}{c}\text { Prosentase } \\
(100 \%)\end{array}$ \\
\hline 1 & Tidak sekolah & 2 & 13 & 3 & 19 \\
2 & Dasar (SD-SMP) & 7 & 44 & 2 & 13 \\
3 & Menengah (SMA) & 4 & 25 & 10 & 63 \\
4 & Tinggi (D3-PT) & 3 & 19 & 1 & 6 \\
\hline & Total & 16 & 100 & 16 & 100 \\
\hline
\end{tabular}

Berdasarkan tabel 3. dapat diinterpretasikan bahwa kelompok Audiovisual terdapat 7 orang (44\%) responden berpendidikan Dasar (SD-SMP) dan kelompok Leaflet terdapat 10 (63\%) responden berpendidikan Menengah 
(SMA), sehingga dapat disimpulkan bahwa hampir setengah responden 14 (44\%) berpendidikan Menengah (SMA).

\section{b. Data Khusus}

4. Keterampilan Pemeriksaan Payudara Sendiri (SADARI) pada kelompok Audiovisual sebelum diberikan pelatihan di Desa Bukur

Keterampilan WUS dalam melakukan deteksi dini kanker payudara dengan Pemeriksaan Payudara Sendiri (SADARI) sebelum diberikan pelatihan di Desa Bukur Tulungagung Tahun 2018 adalah sebagai berikut: Tabel 4. Hasil nilai pre-test keterampilan Pemeriksaan Payudara Sendiri (SADARI) pada kelompok Audiovisual di Desa Bukur Tulungagung tahun 2018

\begin{tabular}{cccc}
\hline No & Pre-Test & Frekuensi & Prosentase (\%) \\
\hline 1 & Tidak Terampil & 7 & 44 \\
2 & Cukup terampil & 5 & 31 \\
3 & Terampil & 3 & 19 \\
4 & Sangat Terampil & 1 & 6 \\
\hline & Total & 32 & 100 \\
\hline
\end{tabular}

Berdasarkan tabel 4. diatas dapat diinterpretasikan bahwa hampir setengah (44 \%) responden tidak terampil melakukan Pemeriksaan Payudara Sendiri (SADARI)

5. Keterampilan Pemeriksaan Payudara Sendiri (SADARI) pada kelompok Leaflet sebelum diberikan Leaflet di Desa Bukur

Keterampilan WUS dalam melakukan deteksi dini kanker payudara dengan Pemeriksaan Payudara Sendiri (SADARI) sebelum diberikan Leaflet di Desa Bukur Tulungagung Tahun 2018 adalah sebagai berikut:

Tabel 5. Hasil nilai pre-test keterampilan Pemeriksaan Payudara Sendiri (SADARI) pada kelompok Leaflet di Desa Bukur Tulungagung tahun 2018

\begin{tabular}{llll}
\hline No & Pre-Test & Frekuensi & Prosentase (\%) \\
\hline
\end{tabular}




\begin{tabular}{cccc}
\hline 1 & Tidak Terampil & 8 & 50 \\
2 & Cukup terampil & 3 & 19 \\
3 & Terampil & 3 & 19 \\
4 & Sangat Terampil & 2 & 13 \\
\hline & Total & 32 & 100 \\
\hline
\end{tabular}

Berdasarkan tabel 5. diatas dapat diinterpretasikan bahwa setengah (50 \%) responden tidak terampil melakukan Pemeriksaan Payudara Sendiri (SADARI)

6. Keterampilan Pemeriksaan Payudara Sendiri (SADARI) pada kelompok Audiovisual setelah diberikan pelatihan di Desa Bukur

Keterampilan WUS dalam melakukan deteksi dini kanker payudara dengan Pemeriksaan Payudara Sendiri (SADARI) setelah diberikan pelatihan di Desa Bukur Tulungagung Tahun 2018 adalah sebagai berikut: Tabel 6. Hasil nilai post-test keterampilan Pemeriksaan Payudara Sendiri (SADARI) pada kelompok Audiovisual di Desa Bukur Tulungagung tahun 2018

\begin{tabular}{cccc}
\hline No & Post-Test & Frekuensi & Prosentase (\%) \\
\hline 1 & Tidak Terampil & 0 & 0 \\
2 & Cukup terampil & 2 & 13 \\
3 & Terampil & 6 & 18 \\
4 & Sangat Terampil & 8 & 50 \\
\hline & Total & 32 & 100 \\
\hline
\end{tabular}

Berdasarkan tabel 6. diatas dapat diinterpretasikan bahwa setengah (50\%) responden sangat terampil melakukan Pemeriksaan Payudara Sendiri (SADARI)

7. Keterampilan Pemeriksaan Payudara Sendiri (SADARI) pada kelompok Leaflet setelah diberikan Leaflet di Desa Bukur

Keterampilan WUS dalam melakukan deteksi dini kanker payudara dengan Pemeriksaan Payudara Sendiri (SADARI) setelah diberikan leaflet di Desa Bukur Tulungagung Tahun 2018 adalah sebagai berikut: 
Tabel 7. Hasil nilai post-test keterampilan Pemeriksaan Payudara Sendiri (SADARI) pada kelompok Audiovisual di Desa Bukur Tulungagung tahun 2018

\begin{tabular}{cccc}
\hline No & Post-Test & Frekuensi & Prosentase (\%) \\
\hline 1 & Tidak Terampil & 1 & 6 \\
2 & Cukup terampil & 3 & 19 \\
3 & Terampil & 8 & 50 \\
4 & Sangat Terampil & 4 & 25 \\
\hline & Total & 32 & 100 \\
\hline
\end{tabular}

Berdasarkan tabel 7. diatas dapat diinterpretasikan bahwa setengah (50 \%) responden terampil melakukan Pemeriksaan Payudara Sendiri (SADARI)

8. Tabulasi silang Keterampilan Pemeriksaan Payudara Sendiri (SADARI) sebelum dan sesudah diberikan pelatihan pada kelompok Audiovisual

Keterampilan pada kelompok Audiovisual dalam melakukan deteksi dini kanker payudara dengan Pemeriksaan Payudara Sendiri (SADARI) sebelum dan sesudah diberikan pelatihan di Desa Bukur Tulungagung Tahun 2018 adalah sebagai berikut:

Tabel 8. Hasil nilai Tabulasi Silang pre-test dan post-test keterampilan Pemeriksaan Payudara Sendiri (SADARI) pada Wanita Usia Subur (WUS) di Desa Bukur Tulungagung tahun 2018

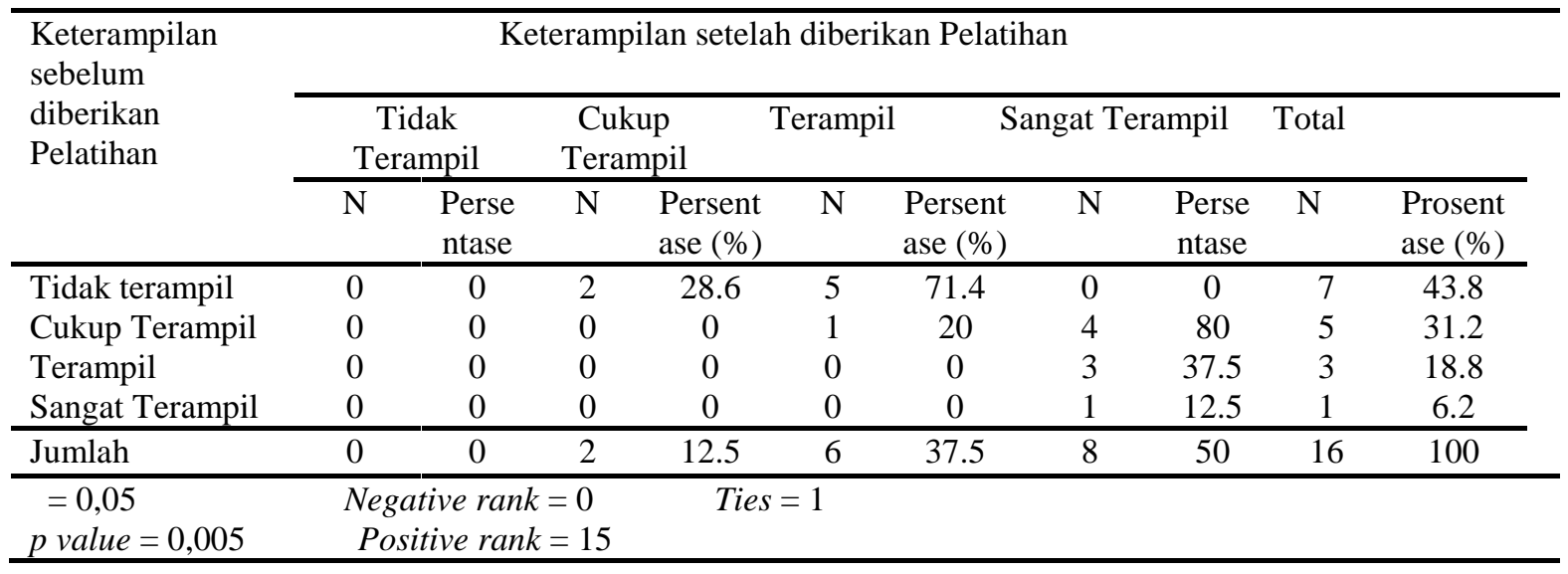


Berdasarkan tabel 8. dapat diketahui bahwa pada kelompok Audiovisual sebagian besar responden mengalami positif ranks yaitu terjadi peningkatan Keterampilan setelah diberikan pelatihan Berdasarkan uji Wilcoxon didapatkan nilai signifikan ( $p$ value $)=0,005(<\alpha=0,05)$ sehingga dapat disimpulkan H0 ditolak dan H1 diterima yang artinya ada perbedaan keterampilan Pemeriksaan Payudara Sendiri (SADARI) antara sebelum dan sesudah diberikan pelatihan dengan metode audiovisual di Desa Bukur Kota Tulungagung tahun 2018.

9. Tabulasi silang Keterampilan Pemeriksaan Payudara Sendiri (SADARI) sebelum dan sesudah diberikan pelatihan pada kelompok Leaflet

Keterampilan pada kelompok Leaflet dalam melakukan deteksi dini kanker payudara dengan Pemeriksaan Payudara Sendiri (SADARI) sebelum dan sesudah diberikan Leaflet di Desa Bukur Tulungagung Tahun 2018 adalah sebagai berikut:

Tabel 9. Hasil nilai Tabulasi Silang pre-test dan post-test keterampilan Pemeriksaan Payudara Sendiri (SADARI) pada Wanita Usia Subur (WUS) di Desa Bukur Tulungagung tahun 2018

\begin{tabular}{|c|c|c|c|c|c|c|c|c|c|c|}
\hline \multirow{3}{*}{$\begin{array}{l}\text { Keterampilan } \\
\text { sebelum } \\
\text { diberikan Leaflet }\end{array}$} & \multicolumn{9}{|c|}{ Keterampilan setelah diberikan Leaflet } & \\
\hline & \multicolumn{2}{|c|}{$\begin{array}{c}\text { Tidak } \\
\text { Terampil }\end{array}$} & \multicolumn{2}{|c|}{$\begin{array}{c}\text { Cukup } \\
\text { Terampil }\end{array}$} & \multicolumn{2}{|c|}{ Terampil } & \multicolumn{2}{|c|}{ Sangat Terampil } & \multicolumn{2}{|l|}{ Total } \\
\hline & $\mathrm{N}$ & $\begin{array}{l}\text { Perse } \\
\text { ntase }\end{array}$ & $\mathrm{N}$ & $\begin{array}{l}\text { Persent } \\
\text { ase }(\%)\end{array}$ & $\bar{N}$ & $\begin{array}{l}\text { Persent } \\
\text { ase }(\%)\end{array}$ & $\bar{N}$ & $\begin{array}{l}\text { Perse } \\
\text { ntase }\end{array}$ & $\mathrm{N}$ & $\begin{array}{l}\text { Prosent } \\
\text { ase }(\%)\end{array}$ \\
\hline Tidak terampil & 1 & 12.5 & 3 & 37.5 & 4 & 50 & 0 & 0 & 8 & 50 \\
\hline Cukup Terampil & 0 & 0 & 0 & 0 & 1 & 33.3 & 2 & 66.7 & 3 & 18.8 \\
\hline Terampil & 0 & 0 & 0 & 0 & 3 & 37.7 & 0 & 0 & 3 & 18.8 \\
\hline Sangat Terampil & 0 & 0 & 0 & 0 & 0 & 0 & 2 & 50 & 2 & 12.5 \\
\hline Jumlah & 1 & 6.2 & 3 & 18.8 & 8 & 50 & 4 & 25 & 16 & 100 \\
\hline $\begin{array}{l}\alpha=0,05 \\
p \text { value }=0,005\end{array}$ & \multicolumn{3}{|c|}{$\begin{aligned} \text { Negative rank } & =0 \\
\text { Positive rank } & =10\end{aligned}$} & \multicolumn{2}{|c|}{ Ties $=6$} & & & & & \\
\hline
\end{tabular}

Berdasarkan tabel 9. dapat diketahui bahwa pada kelompok Leaflet sebagian besar responden mengalami positif ranks yaitu terjadi peningkatan Keterampilan setelah diberikan Leaflet Berdasarkan uji Wilcoxon didapatkan nilai signifikan ( $p$ value $)=0,005(<\alpha=0,05)$ sehingga dapat disimpulkan H0 ditolak dan H1 diterima yang artinya ada 
perbedaan keterampilan Pemeriksaan Payudara Sendiri (SADARI) antara sebelum dan sesudah diberikan pendidikan kesehatan dengan metode leaflet di Desa Bukur Kota Tulungagung tahun 2018.

\section{B. PEMBAHASAN}

Keterampilan merupakan sebuah kemampuan dalam mengoperasikan pekerjaan secara lebih mudah dan tepat. Definisi keterampilan menurut Gordon ini cenderung mengarah pada aktivitas psikomotor (Gordon 2004). Keterampilan berarti mengembangkan pengetahuan yang didapatkan melalui training dan pengalaman dengan melaksanakan beberapa tugas (Iverson, 2002).

Dilihat dari data diatas dapat diketahui bahwa faktor yang dapat menyebabkan ibu tidak dapat melakukan SADARI adalah pendidikan, rata-rata pendidikan adalah pendidikan Dasar sehingga kurang pengetahuan tentang deteksi dini kanker payudara. Selain itu faktor yang dapat menyebabkan ibu tidak dapat melakukan SADARI adalah juga pekerjaan, pada saat diberikan Pre-test menjawab dan melakukannya sebisanya karena mereka sibuk dengan pekerjaannya.

Dilihat dari usia, semua responden berusia 20-35 tahun. Dimana dalam usia tersebut merupakan usia reproduktif yang optimal. Sehingga jika kesehatannya tidak dijaga dengan baik maka akan berpotensi mengembangkan penyakit, dan jika tidak tahu dan tidak melakukan deteksi dini kanker payudara dengan SADARI maka akan berpotensi mengalami kanker payudara.

Setelah diberikan pelatihan terdapat peningkatan ketrampilan hal ini dapat dipengaruhi dari faktor pendidikan. Sebagian besar responden juga berpendidikan menengah, dimana pada pendidikan ini seseorang akan lebih mudah mencari informasi tentang kesehatannya dibandingkan dengan orang yang berpendidikan dibawahnya, sehingga akan lebih mudah bagi responden dalam menangkap materi yang disampaikan oleh peneliti tentang SADARIsebagai deteksi dini kanker payudara. 


\section{DAFTAR PUSTAKA}

Depkes, (2009) Mengenali Kanker Serviks dan Kanker Payudara .Dep Kes RI

Diananda. (2009). Kanker payudara pada perempuan [internet] http://www.kankerpayudarapadaperempuan.com> [diakses tanggal 20 Desember 2013] (2008). Konsep efektifitas. FKM UI

Gordon. (2004) konsep keterampilan [internet] http://www. konsepketerampilan. com> [diakses tanggal 20 desember 2014]

Haryono. (2007). Kejadian kanker pada wanita. [internet] http://kejadiankankerpadawanita.com> [diakses tanggal 20 Desember 2014]

Herijulianti. (2011). Pendidikan kesehatan dan pelatihan. Jakarta, buku kedokteran EGC

Iverson. (2002) konsep keterampilan [internet] http://www. konsepketerampilan. com> [diakses tanggal 20 desember 2014]

Karmila, Mila. (2006) Kanker Payudara [internet] http://www.Kanker Payudara7.blogspot.com> [di Akses Tanggal 20 Desember 2013].

Kumalasari, Intan. (2012) Kesehatan Reproduksi Pada Remaja. Jakarta, Salemba medika

Kurniawan. (2005) konsep tentang efektifitas [internet] http://konseptentang efektifitas.com> [diakses tanggal 20 desember 2014].

Mansjoer, A. (2000) kapita selekta kedokteran jilid 2. Fakultas kedokteran universitas indonesia. Media Aesculapius

Manuaba. (2010) Pemeriksaan Payudara Sendiri [internet] http://creasoft..com> [di akses tanggal 22 Desember 2013].

Mardiana, L. (2009) kanker pada wanita. Jakarta, penebar swadaya.

Notoadmojo, S. (2007) Pendidikan Dan Perilaku Kesehatan. Jakarta, Rineka Cipta.

Cipta.

(2010) Pendidikan Dan Perilaku Kesehatan. Jakarta, Rineka

Rachmat, Mochamad. (2012) Biostatistika. Jakarta, EGC 
Rina. (2008) Tujuan penyuluhan kesehatan [Internet] http://www.google.com [diakses tanggal 15 Januari 2018]

Robbin. (2005) kategori keterampilan [internet] http://www.kategoriketerampilan .com> [diakses tanggal 20 desember 2014]

Suliha. (2002) Konsep penyuluhan [Internet] http//www.org.com [diakses tanggal 15 januari 2018]

Sunaryo. (2006) Konsep Perilaku Kesehatan [internet] http//konsep perilaku menurut HBM.com> [di akses tanggal 15 Januari 2018].

Surjadi (2009) Konsep Psiokologi Remaja. Jakarta, Salemba Medika

Tangkilisan. (2005) ukuran efektifitas [internet] http://www.ukuranefektifitas .com> [diakses tanggal 20 Desember 2014]

Wahyuningsih. (2012) jumlah penderita kanker di dunia [internet] http://jumlahpenderitakankerdidunianaik300persenpadatahun2030.com> [diakses tanggal 20 Desember 2014]

Widyastuti, yani. (2009) Kesehatan Reproduksi. Yogyakarta, Fitramaya.

Wulandari, S. (2013) efektifitas pelatihan senam nifas terhadap keterampilan ibu dalam melakukan senam nifas pada ibu nifas. Tulungagung 